\title{
Effect of oat saponins on plasma and liver lipids in gerbils (Meriones unguiculatus) and rats
}

\author{
BY G. ÖNNING AND N.-G. ASP \\ Department of Applied Nutrition and Food Chemistry, Chemical Centre, University of Lund, \\ Box 124, S-221 00 Lund, Sweden
}

(Received 7 March 1994 - Revised 13 May 1994 - Accepted 7 June 1994)

\begin{abstract}
The effects of oat saponins (a mixture of avenacosides $\mathbf{A}$ and B) on plasma and liver lipids in gerbils (Meriones unguiculatus) and rats were investigated. Cholesterol-containing diets high in total and saturated fat and with different avenacoside contents (zero (ethanol-extracted oats), normal (oats) and twice normal (ethanol-extracted oats plus added avenacosides)) were used. Compared with a cellulose control group the oat diets in both species gave a significantly higher cholesterol content in the HDL fraction and a significantly lower liver cholesterol content. No significant differences in total plasma cholesterol, HDL-cholesterol and plasma triacylglycerols were found, however, between the groups fed on oats with different avenacoside content. The liver weight, total liver cholesterol and free liver cholesterol were also similar, whereas the liver lipid content was significantly lower in rats given the highest amount of avenacosides compared with zero or normal amounts. The tendency was the same in gerbils. Thus, the oat saponins had only minor effects on lipid metabolism in gerbils and rats.
\end{abstract}

Gerbil: Lipid metabolism: Oats: Saponins

Oats have well-documented blood-cholesterol-lowering effects (Ripsin \& Keenan, 1992). There is evidence that the soluble fibre in oats, $\beta$-glucan, is responsible for this effect (Chen et al. 1981; Shinnick et al. 1990). In rats given atherogenic diets a dose-response relationship has been demonstrated between the $\beta$-glucan content and the lipid-lowering effect. The average content of $\beta$-glucan in oats is about $50 \mathrm{~g} / \mathrm{kg}$ (Asp et al. 1991). The original mechanism proposed for the action of soluble fibre, i.e. increased ileal sequestration of bile acids, has been confirmed in both animals and man (Illman \& Topping, 1985; Andersson, 1992). The propionate formed when the fibre is fermented in the colon could also contribute by inhibiting cholesterol biosynthesis (Chen \& Anderson, 1984).

Another constituent in oats which could affect the cholesterol concentration in blood is the saponins. Saponins are glycosides with steroid or triterpenoid aglycon (Price et al. 1987). A hypothesis that saponins induce the adsorption of bile acids to dietary fibre has been proposed (Oakenfull et al. 1979). Bile acid excretion is increased and the blood cholesterol level reduced when rats, pigs and humans are given saponin-rich diets (Potter et al. 1980; Topping et al. 1980; Oakenfull et al. 1984). This hypothesis was not supported, however, by findings of a rat study with lucerne (Medicago sativa) and saponin-free lucerne (Story et al. 1984). The latter diet increased bile acid excretion more than the former.

The main saponins in oats are avenacosides A and B (Tschesche et al. 1969; Tschesche \& Lauren, 1971). So far, there have been no studies which have investigated the cholesterollowering effect of these oat saponins.

Gerbils (Meriones unguiculatus), compared with rats, react more like humans to fat in the diet, i.e. saturated fat increases blood cholesterol (Nicolosi et al. 1981). On the other hand, gerbils are more sensitive to dietary cholesterol than man. They do not develop 
atherosclerosis (Gordon \& Cekleniak, 1961) but a diet containing $2 \mathrm{~g}$ cholesterol $/ \mathrm{kg}$ causes severe hypercholesterolaemia and high levels of cholesteryl esters in the liver, ultimately leading to cirrhosis (Temmerman et al. 1988). In rats, 5-10 g cholesterol $/ \mathrm{kg}$ diet, and often also bile acids, must be added to produce elevated blood cholesterol levels (Shinnick et al. 1990).

In the present study we fed gerbils on diets containing $1 \mathrm{~g}$ cholesterol $/ \mathrm{kg}$ and $40 \%$ of the energy from fat, i.e. similar to Western diets. For the rats the cholesterol content was increased to $5 \mathrm{~g} / \mathrm{kg}$ diet with the same fat content. The experimental diets contained either oats, ethanol-extracted oats in which most of the saponins had been removed, or ethanolextracted oats plus added avenacosides $(0.7 \mathrm{~g} / \mathrm{kg}$ diet $)$. In this way oat diets with three levels of avenacosides (zero, normal, twice normal) were prepared. As controls we used one diet with cellulose, known not to affect blood cholesterol, and another with guar gum, known to reduce hypercholesterolaemia in rats. To our knowledge gerbils have not been used previously to study the effects of dietary fibre on plasma lipid levels.

\section{MATERIALS AND METHODS}

Preparation and analysis of oatmeals

Oatmeal of the variety Sang was obtained from Kungsörnen, Järna, Sweden. A portion of the oatmeal was extracted with ethanol to obtain a virtually saponin-free product. This procedure was carried out by Swedish Protein, Väröbacka, Sweden. The meal was extracted twice at room temperature with $700 \mathrm{ml}$ ethanol/1 $(1: 4, \mathrm{w} / \mathrm{v})$. After this treatment $8 \%$ of the avenacosides remained, therefore, the meal was extracted a third time, now with ethanol $(950 \mathrm{ml} / \mathrm{l})$ at $55-60^{\circ}$ for $24 \mathrm{~h}$. This meal, containing about $2 \%$ of the initial amount of avenacosides (Table 1), was used in the study.

The oatmeal and the ethanol-extracted oatmeal were analysed for avenacosides A and B using HPLC technique (Önning \& Asp, 1993). The meal was first defatted with light petroleum(b.p. $60-80^{\circ}$ )and, thereafter, thesaponinswereextracted withmethanol.Aportion of the extract $(20 \mu \mathrm{l})$ was injected onto an octyl silica column (LiChroCART, $125 \times 4 \mathrm{~mm}$; Merck, Darmstadt, Germany) and the saponins were eluted with a gradient of $250-400 \mathrm{ml}$ acetonitrile/1 for $15 \mathrm{~min}$. A Varian 5000 Liquid Chromatograph was used and the flowrate was $2 \mathrm{ml} / \mathrm{min}$. The saponins were detected by u.v. absorption at $200 \mathrm{~nm}$ and calibration was performed by injecting known amounts of avenacosides $\mathrm{A}$ and $\mathrm{B}$. The avenacoside $A$ and B standards used were prepared from oatmeal (Önning et al. 1994).

The meals were analysed for dietary fibre (Asp et al. 1983), $\beta$-glucan (McCleary \& Glennie-Holmes, 1985) and starch (Holm et al. 1986) using enzymic methods. Protein was analysed by the Kjeldahl procedure and tocopherols and tocotrienols using an HPLC technique (Bourgeois et al. 1985; Håkansson et al. 1987). Fat (EU Method, 1971) and fatty acid (Berg, 1990) analyses were performed at the Swedish Meat Research Institute, Kävlinge, Sweden.

\section{Isolation of avenacosides}

Avenacosides A and B were extracted from $20 \mathrm{~kg}$ oatmeal (var. Sang, Kungsörnen, Järna, Sweden) at Nestlé Research Centre, Lausanne, Switzerland. The meal was first defatted with hexane and, thereafter extracted with methanol at $25^{\circ}$. The methanol extract was fractionated by portioning into butanol-water $(1: 1, \mathrm{v} / \mathrm{v})$. The phases were allowed to separate and the butanol phase containing the saponins was evaporated to dryness under reduced pressure. The residue was purified using chromatography on silica gel SI-60. Elution was carried out using a stepwise gradient with chloroform and increasing amounts of methanol (0-250 ml methanol/1). The fractions containing saponins, confirmed by thinlayer chromatographic analysis (Lütz, 1980), were pooled and concentrated. The resulting saponin material was further purified by gel filtration (Sephadex LH-20) with ethanol as the 
Table 1. Nutrient content in oatmeal and ethanol-extracted oatmeal* ( $\mathrm{g} / \mathrm{kg}$ dry matter) (Values are means for two or three analyses)

\begin{tabular}{|c|c|c|}
\hline Nutrient & Oatmeal & EtOH-extracted oatmeal \\
\hline \multicolumn{3}{|l|}{ Dietary fibre } \\
\hline Total & 97 & 118 \\
\hline Insoluble & 49 & 58 \\
\hline Soluble & 48 & 59 \\
\hline$\beta$-Glucan & 49 & 62 \\
\hline Starch & 645 & 668 \\
\hline Protein $(\mathrm{N} \times 5.83)$ & 131 & 144 \\
\hline \multicolumn{3}{|l|}{ Fat } \\
\hline \multirow{2}{*}{\multicolumn{3}{|c|}{ Fatty acid composition $(\mathrm{g} / 100 \mathrm{~g})$}} \\
\hline & & \\
\hline $\mathrm{C}_{6}-\mathrm{C}_{12}$ & $<0.1$ & $<0-1$ \\
\hline $\mathrm{C}_{14}$ & 0.3 & 0.5 \\
\hline $\mathrm{C}_{16}$ & 16.9 & $26 \cdot 5$ \\
\hline$C_{16: 1}$ & 0.2 & $0 \cdot 3$ \\
\hline $\mathrm{C}_{18}$ & 1.5 & 1.6 \\
\hline$C_{18: 1}^{18}$ & $35 \cdot 3$ & $27 \cdot 2$ \\
\hline $\mathrm{C}_{18: 8}$ & $40 \cdot 2$ & $34 \cdot 4$ \\
\hline $\mathrm{C}_{18: 3}$ & $1 \cdot 3$ & 0.8 \\
\hline $\mathrm{C}_{20}$ & 0.2 & 0.5 \\
\hline$C_{20: 1}^{20}$ & 0.7 & $<0.1$ \\
\hline $\mathrm{C}_{22} 201$ & $0 \cdot 3$ & 0.8 \\
\hline $\mathrm{C}_{22,1}$ & 0.1 & $3 \cdot 0$ \\
\hline $\mathrm{C}_{24}^{28.1}$ & $0 \cdot 1$ & $<0.1$ \\
\hline $\mathrm{C}_{34: 1}$ & 0.1 & $<0.1$ \\
\hline \multicolumn{3}{|l|}{ Saponins } \\
\hline Avenacoside A & $0 \cdot 30$ & 0.007 \\
\hline Avenacoside B & 0.19 & 0.006 \\
\hline$\alpha$-Tocopherol & 0.0022 & $<0.0001$ \\
\hline
\end{tabular}

* For details of extraction procedure, see p. 276.

eluting solvent. In the next purification step a column was filled with $\mathrm{RP}-\mathrm{C}_{\mathbf{1 8}}$ and equilibrated in $600 \mathrm{ml}$ methanol/1. The saponin sample was loaded onto the column which was eluted first with $600 \mathrm{ml}$ methanol $/ 1$ and then $800 \mathrm{ml}$ methanol/1. The saponincontaining fractions were pooled and evaporated to dryness, and about $4 \mathrm{~g}$ of a yellowcoloured powder were obtained after this procedure. The contents of avenacosides $\mathrm{A}$ and $B$ were 0.52 and $0.09 \mathrm{~g} / \mathrm{g}$ dry matter respectively. Final purification was achieved using Bond Elut cartridges (10 g, $\mathrm{C}_{18}$; Analytichem International, Varian, Harbour City, CA, USA) according to the method of Önning \& Asp (1993). The resulting material was slightly yellow and contained $0.69 \mathrm{~g}$ avenacoside $\mathrm{A}$ and $0.14 \mathrm{~g}$ avenacoside $\mathrm{B} / \mathrm{g}$ dry matter. This preparation was added to the ethanol-extracted meal to obtain an avenacoside content $(1 \mathrm{~g} / \mathrm{kg})$ which was about twice that in the original meal.

\section{Preparation of diets}

The experimental diets, except the rat-pellet diet, were balanced regarding dietary fibre, carbohydrate, protein and fat (Table 2). The gerbil and rat diets were the same in all respects except for the cholesterol content. The main components were cellulose (Whatman, Maidstone, Kent), guar gum (Copenhagen Pectin Factory Ltd, Skensved, Denmark), wheat starch (Excelsior, Holland), sucrose (Swedish Sugar Company, Arlöv, Sweden), casein (ICN Biochemicals, Cleveland, OH, USA) and a fat mixture containing coconut oil, palm oil and rapeseed oil (Karlshamns Oils \& Fats AB, Karlshamn, Sweden). Other 
Table 2. Composition of the experimental diets $(\mathrm{g} / \mathrm{kg}$ dry matter)

\begin{tabular}{|c|c|c|c|c|c|}
\hline Ingredient & Cellulose & Guar gum & $\begin{array}{l}\text { Ethanol- } \\
\text { extracted } \\
\text { oatmealf }\end{array}$ & Oatmeal & $\begin{array}{c}\text { Ethanol- } \\
\text { extracted } \\
\text { oatmeal+ } \\
\text { saponins }\end{array}$ \\
\hline \multicolumn{6}{|l|}{ Dietary fibre } \\
\hline Total & 65 & 65 & 65 & 65 & 65 \\
\hline Cellulose & 65 & - & - & - & - \\
\hline Guar gum & - & 65 & - & - & - \\
\hline Oatmeal & - & 一 & 65 & 65 & 65 \\
\hline \multicolumn{6}{|l|}{ Carbohydrate } \\
\hline Total & 520 & 520 & 520 & 520 & 520 \\
\hline Sucrose & 90 & 90 & 90 & 90 & 90 \\
\hline Wheat starch & 430 & 430 & 60 & - & 60 \\
\hline Oatmeal & - & - & 370 & 430 & 370 \\
\hline \multicolumn{6}{|l|}{ Protein } \\
\hline Total & 150 & 150 & 150 & 150 & 150 \\
\hline Casein & 150 & 150 & 70 & 60 & 70 \\
\hline Oatmeal & - & - & 80 & 90 & 80 \\
\hline L-methionine & 1 & 1 & 1 & 1 & 1 \\
\hline Taurine & 5 & 5 & 5 & 5 & 5 \\
\hline \multicolumn{6}{|l|}{ Fat } \\
\hline Total & 200 & 200 & 200 & 200 & 200 \\
\hline Coconut oil & 100 & 100 & 100 & 100 & 100 \\
\hline Palm oil & 50 & 50 & 50 & 50 & 50 \\
\hline Oatmeal & - & - & 8 & 50 & 8 \\
\hline Fat mix* & 50 & 50 & 42 & - & 42 \\
\hline Mineral mix $\dagger$ & 48 & 48 & 48 & 48 & 48 \\
\hline Vitamin mix & 8 & 8 & 8 & 8 & 8 \\
\hline Choline chloride & 2 & 2 & 2 & 2 & 2 \\
\hline \multicolumn{6}{|l|}{ Cholesterol } \\
\hline Gerbil & 1 & 1 & 1 & 1 & 1 \\
\hline Rat & 5 & 5 & 5 & 5 & 5 \\
\hline Avenacosides & - & - & - & 0.35 & 0.70 \\
\hline
\end{tabular}

* The fat mix was added to balance the oatmeal fat and consisted of $(\mathrm{g} / \mathrm{kg}):$ palm oil 260 , rapeseed oil 150 , maize oil 590 .

$\uparrow$ For details of composition, see Nyman et al. (1990).

¥ For details of extraction procedure, see p. 276.

ingredients in the diets were L-methionine (Merck), taurine (Sigma Chemical Company, St Louis, MO, USA), mineral and vitamin mix (Hospital Pharmacy, Lund, Sweden), and choline chloride (Kebo Lab AB, Stockholm, Sweden). The gerbil and rat diets contained 1 and $5 \mathrm{~g}$ cholesterol (crystalline cholesterol; Merck) $/ \mathrm{kg}$ respectively. In these diets $40 \%$ of the energy comes from fat, $47 \%$ from carbohydrate and $13 \%$ from protein. The fats were used in proportions adjusted to achieve a similar fatty acid composition in all the diets (Table 3).

The rat-pellet diet (R3; Lactamin, Stockholm, Sweden) contained (g/kg dry matter): protein 240, fat 60, crude fibre 40, carbohydrate 590. Analysis of dietary fibre (Asp et al. 1983) gave a total content of $171 \mathrm{~g} / \mathrm{kg}: 140 \mathrm{~g}$ insoluble and $31 \mathrm{~g}$ soluble fibre.

\section{Experimental design}

Male gerbils (Centre d'Elevage $\mathbf{R}$. Janvier, Le-Genest-St-Isle, France) and male rats (Sprague-Dawley; B \& K Universal AB, Sollentuna, Sweden) were used. The gerbils were divided into five groups (fourteen in each group) with initial mean weights of 51 (SD 3) $\mathrm{g}$ and housed two per stainless-steel cage. The rats were housed individually and six groups 
Table 3. Fatty acid composition ( $\mathrm{g} / 100 \mathrm{~g}$ fatty acids) of the experimental diets*

\begin{tabular}{|c|c|c|c|}
\hline Fatty acid & Cellulose, guar gum & Oatmeal & Ethanol-extracted oatmeal $\dagger$ \\
\hline $\begin{array}{l}C_{6} \\
C_{8} \\
C_{10} \\
C_{12} \\
C_{14} \\
C_{16} \\
C_{16: 1} \\
C_{18} \\
C_{18: 1} \\
C_{18: 2} \\
C_{18: 8} \\
C_{20} \\
C_{20: 1} \\
C_{22} \\
C_{22: 1} \\
C_{24} \\
C_{24: 1} \\
\text { Total saturated fatty acids } \\
P: S\end{array}$ & $\begin{array}{r}0.3 \\
3 \cdot 8 \\
2 \cdot 8 \\
22 \cdot 3 \\
9 \cdot 4 \\
20 \cdot 3 \\
0 \cdot 1 \\
3 \cdot 1 \\
22 \cdot 8 \\
14 \cdot 1 \\
0 \cdot 6 \\
0 \cdot 2 \\
0.2 \\
0.1 \\
\frac{1}{0.1} \\
\frac{62 \cdot 4}{0.24}\end{array}$ & $\begin{array}{r}0 \cdot 3 \\
3 \cdot 8 \\
2 \cdot 8 \\
22 \cdot 3 \\
9 \cdot 4 \\
19 \cdot 9 \\
0 \cdot 1 \\
2 \cdot 9 \\
23 \cdot 0 \\
13 \cdot 9 \\
0 \cdot 4 \\
0 \cdot 2 \\
0 \cdot 3 \\
0 \cdot 1 \\
- \\
- \\
- \\
61 \cdot 7 \\
0 \cdot 23\end{array}$ & $\begin{array}{r}0 \cdot 3 \\
3 \cdot 8 \\
2 \cdot 8 \\
22 \cdot 3 \\
9 \cdot 4 \\
22 \cdot 4 \\
0 \cdot 1 \\
2 \cdot 9 \\
20 \cdot 8 \\
12 \cdot 3 \\
0 \cdot 3 \\
0 \cdot 3 \\
0 \cdot 1 \\
0.2 \\
0.8 \\
- \\
- \\
64 \cdot 4 \\
0.20\end{array}$ \\
\hline
\end{tabular}

P:S, polyunsaturated fatty acids: saturated fatty acids.

- For details of composition, see Tables 1 and 2.

$\dagger$ For details of extraction procedure, see p. 276.

of rats with a mean initial weight of 152 (SD 5) $\mathrm{g}$ were selected. Each group consisted of eight animals, except for the group fed on the diet with added saponins in which there were only five animals due to the limited amount of saponins available. The animals were kept in air-conditioned rooms, at $25^{\circ}$ and $50 \%$ relative humidity, with free access to water. A $12 \mathrm{~h}$ light-dark cycle was used.

The different diets were fed $a d$ lib. in metal containers designed to give minimal losses. Feed consumption was registered every second day and the weight of the animals weekly. The animals were acclimatized on pellets for $2 \mathrm{~d}$. One group of rats remained on this diet as a control, while the rest were transferred to the test diets. The gerbils were fed on their diets for $21 \mathrm{~d}$, except for those given the cellulose diet which was discontinued after $16 \mathrm{~d}$. The rats were given the diets for $19 \mathrm{~d}$.

After the feeding period the animals were fasted overnight and killed by $\mathrm{CO}_{2}$ narcosis. Blood was withdrawn by cardiac puncture into tubes containing sodium EDTA as an anticoagulant. The plasma was separated by centrifugation at $10000 \mathrm{~g}$, for $5 \mathrm{~min}$, then the plasma samples were refrigerated. The liver was excised, rinsed in $\mathrm{NaCl}$ solution $(9 \mathrm{~g} / 1$ distilled water), blotted dry, weighed and frozen in $\mathrm{NaCl}$ solution.

The study was approved by the Ethical Committee for Animal Studies at the University of Lund.

\section{Analysis of lipids}

The plasma samples were analysed within $24 \mathrm{~h}$ for total cholesterol, HDL-cholesterol and triacylglycerols using a Reflotron instrument (Boehringer-Mannheim). The apparatus was standardized throughout the analysis using control serum: Precinorm U (total cholesterol, triacylglycerols) and Precinorm HDL. The coefficients of variation for total cholesterol, HDL-cholesterol and triacylglycerol determinations were $1.4,4.5$ and $3.3 \%$ respectively. The cholesterol content in the plasma from the rats was below the detection limit 
( $<2.59 \mathrm{mmol} / 1)$ and, thus, the plasma content was determined using the Sigma cholesterol diagnostic kit (Sigma chemical Co., St Louis, MO, USA). The two procedures gave almost identical results when tested on rat plasma containing $2 \cdot 7$ and $3.1 \mathrm{mmol}$ total cholesterol/1 respectively. Non-HDL-cholesterol, representing mainly the LDL-cholesterol, was calculated as total minus HDL-cholesterol.

Liver lipids were extracted with a chloroform-methanol mixture using the method of Folch et al. (1956). Total liver lipid content was determined gravimetrically. The Sigma diagnostic kit was used to determine the total liver cholesterol. A detergent, Triton X-100 $(2.5 \mathrm{mg})$, was added to the extract and the solution was evaporated under $\mathrm{N}_{2}$ gas before the analysis (Carlson \& Goldfarb, 1977). Free liver cholesterol was determined with the Boehringer Mannheim cholesterol test (Boehringer Mannheim Scandinavia AB, Bromma, Sweden).

All analyses were performed at least in duplicate.

\section{Statistical evaluation}

The SPSS computer program was used and group means were compared by one-way analysis of variance followed by Duncan's multiple-range test. Values for $\boldsymbol{P}<0.05$ were considered significantly different. For total liver cholesterol (rats) the standard deviation was approximately proportional to the means and, therefore, a logarithmic transformation was used to stabilize the variance in this case. For final body weight and feed intake there were significant differences in variances between the dietary groups, and the $t$ test for independent samples was used. Plasma triacylglycerol values followed a skewed distribution and the non-parametric Kruskal-Wallis test was used.

\section{RESULTS}

\section{Nutrient content in the oatmeal and the ethanol-extracted oatmeal}

Analytical results are presented in Table 1. Avenacoside A and B contents were reduced from 0.49 to $0.013 \mathrm{~g} / \mathrm{kg}$ dry matter by ethanol extraction and large amounts of fats $(85 \%)$ were also extracted by the ethanol. $\alpha$-Tocopherol could be detected in the untreated meal but not in the extracted meal. Tocotrienols may affect the blood cholesterol level (Querishi et al. 1986) but neither of the meals contained any detectable tocotrienols. The other nutrients (dietary fibre, starch, protein) were affected to a minor extent; there was a slight increase in dietary fibre content and, calculated for fat-free material, a slight reduction in starch content after ethanol extraction. This indicates the formation of some resistant starch by the extraction process.

\section{Growth and feed intake}

There were no significant differences in initial weight between the groups of either gerbils or rats (Table 4). Due to several spontaneous deaths in the gerbil group fed on cellulose, this group was withdrawn after $16 \mathrm{~d}$. The other groups were fed for $21 \mathrm{~d}$ (gerbils) and $19 \mathrm{~d}$ (rats). For both species the intake of the guar-gum diet was lower than that of the other diets and, consequently, the mean final body weight for this group was significantly lower. The intake of the cellulose diet was also lower in rats, especially at the beginning of the trial (values not shown). The groups fed on diets containing oats with different saponin contents had similar feed intakes and final body weights.

\section{Plasma lipids}

The plasma lipid values are presented in Table 5. The total plasma cholesterol contents for the gerbils were between 4.3 and $5.1 \mathrm{mmol} / 1$ and were not significantly different between the dietary groups. For the rats the guar-gum group had a total plasma cholesterol level of 
Table 4. The effects of oat saponins on the growth and feed intake of gerbils (Meriones unguiculatus ) and rats given different diets*

(Mean values with their standard errors)

\begin{tabular}{|c|c|c|c|c|c|c|c|}
\hline \multirow[b]{2}{*}{ Diet } & \multirow[b]{2}{*}{$n$} & \multicolumn{2}{|c|}{ Initial body wt (g) } & \multicolumn{2}{|c|}{ Final body wt $\dagger$ (g) } & \multicolumn{2}{|c|}{ Intake $(\mathrm{g} / \mathrm{d}$ per animal) } \\
\hline & & Mean & SE & Mean & SE & Mean & SE \\
\hline \multicolumn{8}{|l|}{ Gerbilst } \\
\hline Cellulose & 7 & $51.9^{\mathrm{a}}$ & 0.9 & $55 \cdot 5$ & $1 \cdot 1$ & $4 \cdot 4^{a}$ & 0.2 \\
\hline Guar gum & 13 & $50 \cdot 9^{8}$ & $1 \cdot 2$ & $51 \cdot 7^{b}$ & $2 \cdot 6$ & $3.9^{b}$ & $0 \cdot 1$ \\
\hline EtOH oats & 14 & $51 \cdot 5^{\mathrm{a}}$ & 1.0 & $59 \cdot 4^{a}$ & $1 \cdot 0$ & $4 \cdot 8^{\mathrm{a}}$ & 0.02 \\
\hline Oats & 14 & $51 \cdot 5^{\mathrm{B}}$ & 0.6 & $59 \cdot 7^{\mathrm{a}}$ & $1 \cdot 1$ & $4 \cdot 8^{2}$ & 0.05 \\
\hline EtOH oats + saponins & 14 & $51 \cdot 1^{\mathrm{a}}$ & 0.7 & $58 \cdot 5^{\mathrm{a}}$ & $1 \cdot 2$ & $4 \cdot 8^{\mathrm{a}}$ & $0 \cdot 1$ \\
\hline \multicolumn{8}{|l|}{ Rats $\dagger$} \\
\hline Pellets & 8 & $151.9^{\mathrm{a}}$ & $2 \cdot 1$ & $265 \cdot 5^{\text {be }}$ & $6 \cdot 1$ & $17 \cdot 3^{\mathrm{a}}$ & 0.4 \\
\hline Cellulose & 8 & $152 \cdot 7^{\mathrm{a}}$ & $2 \cdot 0$ & $259 \cdot 7^{\mathrm{ac}}$ & 11.9 & $14 \cdot 3^{\mathrm{c}}$ & $1 \cdot 0$ \\
\hline Guar gum & 8 & $152 \cdot 4^{\mathrm{a}}$ & $1 \cdot 7$ & $220 \cdot 0^{d}$ & $3 \cdot 7$ & $10.9^{d}$ & $0 \cdot 3$ \\
\hline EtOH oats & 8 & $151 \cdot 7^{2}$ & $1 \cdot 1$ & $282 \cdot 0^{\mathrm{n}}$ & $3 \cdot 4$ & $16 \cdot 6^{\mathrm{ac}}$ & 0.4 \\
\hline Oats & 8 & $152 \cdot 3^{\mathrm{a}}$ & $1 \cdot 6$ & $274 \cdot 4^{\mathrm{sc}}$ & 6.2 & $15 \cdot 6^{\mathrm{bc}}$ & 0.5 \\
\hline EtOH oats + saponins & 5 & $151 \cdot 6^{a}$ & 3.0 & $270 \cdot 0^{\mathrm{ac}}$ & $5-0$ & $16 \cdot 0^{\mathrm{be}}$ & 0.3 \\
\hline
\end{tabular}

a-d Means within columns with the same superscript letter were not significantly different $(P>0.05)$.

EtOH oats, ethanol-extracted oats.

* For details of animals and diets, see Tables 1-3 and pp. 276-278.

$\dagger$ Values for gerbils after $21 \mathrm{~d}$ on the diet except for the cellulose diet which was fed for $16 \mathrm{~d}$. The rats were fed for $19 \mathrm{~d}$.

Table 5. The effects of oat saponins on plasma lipid concentrations (mmol/l) for gerbils (Meriones unguiculatus) and rats given different diets*

(Mean values with their standard errors)

\begin{tabular}{|c|c|c|c|c|c|c|c|c|}
\hline \multirow[b]{2}{*}{ Diet } & \multicolumn{2}{|c|}{ Total cholesterol } & \multicolumn{2}{|c|}{ HDL-cholesterol } & \multicolumn{2}{|c|}{$\begin{array}{l}\text { Non-HDL- } \\
\text { cholesterol }\end{array}$} & \multicolumn{2}{|c|}{ Triacylglycerols } \\
\hline & Mean & $\mathbf{S E}$ & Mean & $\mathbf{S E}$ & Mean & SE & Mean & $\mathbf{S E}$ \\
\hline \multicolumn{9}{|l|}{ Gerbils $†$} \\
\hline Cellulose & $5 \cdot 0^{\mathrm{s}}$ & $1 \cdot 5$ & $1.9^{\mathrm{a}}$ & 0.2 & $3 \cdot 1^{\mathrm{n}}$ & 0.6 & $0.9^{\mathrm{a}}$ & 0.06 \\
\hline Guar gum & $4-3^{a}$ & $1 \cdot 1$ & $2 \cdot 3^{b}$ & 0.2 & $1.9^{b}$ & 0.2 & $1 \cdot 3^{\mathrm{a}}$ & 0.1 \\
\hline EtOH oats & $4 \cdot 8^{\mathrm{a}}$ & 1.0 & $2 \cdot 5^{\mathrm{b}}$ & 0.1 & $2 \cdot 3^{b}$ & 0.1 & $1 \cdot 2^{\mathrm{a}}$ & 0.2 \\
\hline Oats & $5 \cdot 1^{\mathrm{e}}$ & 1.0 & $2 \cdot 6^{b}$ & 0.1 & $2 \cdot 5^{\mathrm{ab}}$ & 0.2 & $1 \cdot 0^{\mathrm{a}}$ & 0.05 \\
\hline EtOH oats + saponins & $4 \cdot 7^{a}$ & $1 \cdot 0$ & $2 \cdot 5^{\mathrm{b}}$ & 0.1 & $2 \cdot 2^{b}$ & 0.2 & $1 \cdot 1^{\mathrm{a}}$ & $0 \cdot 1$ \\
\hline \multicolumn{9}{|l|}{ Rats $\dagger$} \\
\hline Pellets & $1.9^{D}$ & 0.1 & $1 \cdot 1^{b c}$ & 0.1 & $0.9^{b c}$ & 0.06 & $0.8^{\mathrm{a}}$ & 0.05 \\
\hline Cellulose & $2 \cdot 0^{\mathrm{b}}$ & 0.1 & $0.9^{c}$ & 0.06 & $1 \cdot 1^{\mathrm{ac}}$ & 0.08 & $0.8^{2}$ & 0.07 \\
\hline Guar gum & $2 \cdot 5^{\mathrm{a}}$ & $0 \cdot 1$ & $1 \cdot 3^{\mathrm{A}}$ & 0.07 & $1 \cdot 2^{\mathrm{u}}$ & $0 \cdot 10$ & $1 \cdot 1^{a}$ & 0.08 \\
\hline EtOH oats & $2 \cdot 1^{b}$ & 0.1 & $1 \cdot 3^{\mathrm{a}}$ & $0 \cdot 1$ & $0.8^{\mathrm{b}}$ & 0.07 & $0.9^{\mathrm{s}}$ & 0.05 \\
\hline Oats & $2 \cdot 1^{\mathrm{ab}}$ & 0.1 & $1 \cdot 2^{a}$ & 0.09 & $0.9^{\mathrm{bc}}$ & 0.04 & $0.9^{a}$ & 0.08 \\
\hline EtOH oats + saponins & $2 \cdot 1^{\mathrm{b}}$ & 0.04 & $1 \cdot 1^{\mathrm{se}}$ & 0.04 & $1.0^{\text {abo }}$ & 0.06 & $1 \cdot 0^{a}$ & 0.04 \\
\hline
\end{tabular}

s-c Means within columns with the same superscript letter were not significantly different $(P>0.05)$.

EtOH oats, ethanol-extracted oats.

* For details of animals and diets, see Tables 1-3 and pp. 276-278.

$\dagger$ The feeding period was $21 \mathrm{~d}$ for gerbils, except for the cellulose diet which was fed for $16 \mathrm{~d}$, and $19 \mathrm{~d}$ for rats. 
Table 6. The effects of oat saponins on liver weight and liver lipid values for gerbils (Meriones unguiculatus) and rats given different diets*

(Mean values with their standard errors)

\begin{tabular}{|c|c|c|c|c|c|c|c|c|c|c|}
\hline \multirow[b]{3}{*}{ Diet } & \multicolumn{4}{|c|}{ Liver wt } & \multirow{2}{*}{\multicolumn{2}{|c|}{$\begin{array}{l}\text { Total lipid } \\
\text { content } \\
\text { (mg/g wet } \\
\text { tissue) }\end{array}$}} & \multicolumn{4}{|c|}{ Cholesterol (mg/g wet tissue) } \\
\hline & \multicolumn{2}{|c|}{$\mathbf{g}$} & \multicolumn{2}{|c|}{$\mathrm{g} / \mathrm{kg}$ body wt } & & & \multicolumn{2}{|c|}{ Total } & \multicolumn{2}{|c|}{ Free } \\
\hline & Mean & SE & Mean & $\mathbf{S E}$ & Mean & SE & Mean & $\mathrm{SE}$ & Mean & SE \\
\hline \multicolumn{11}{|l|}{$\overline{\text { Gerbils } \dagger}$} \\
\hline Cellulose & $1.9^{\mathrm{a}}$ & 0.08 & $34^{\mathrm{a}}$ & 1.0 & $117^{\mathrm{a}}$ & $10-2$ & $10 \cdot 4^{\mathrm{a}}$ & $0 \cdot 6$ & $2 \cdot 0^{\mathrm{a}}$ & 0.05 \\
\hline Guar gum & $1.9^{\mathrm{a}}$ & 0.09 & $37^{\mathrm{a}}$ & 0.5 & $123^{8}$ & 8.0 & $5 \cdot 5^{\mathrm{b}}$ & 0.5 & $1.8^{\mathrm{b}}$ & 0.04 \\
\hline EtOH oats & $2 \cdot 1^{\mathrm{a}}$ & 0.06 & $35^{\mathrm{a}}$ & 0.7 & $116^{\mathrm{a}}$ & 6.9 & $6.9^{\mathrm{c}}$ & 0.2 & $1.7^{b}$ & 0.04 \\
\hline Oats & $2 \cdot 1^{\mathrm{a}}$ & 0.06 & $34^{\mathrm{a}}$ & 0.8 & $115^{a}$ & $6 \cdot 4$ & $6 \cdot 5^{b c}$ & 0.3 & $1.8^{\mathrm{b}}$ & 0.04 \\
\hline EtOH oats + saponins & $2 \cdot 0^{\mathrm{a}}$ & 0.05 & $35^{\mathrm{a}}$ & 0.8 & $111^{\mathrm{a}}$ & $4 \cdot 8$ & $6 \cdot 5^{\mathrm{c}}$ & 0.3 & $1 \cdot 6^{\mathrm{b}}$ & 0.04 \\
\hline \multicolumn{11}{|l|}{ Rats $\dagger$} \\
\hline Pellets & $9.9^{\mathrm{b}}$ & 0.5 & $37^{\mathrm{b}}$ & 1 & $50^{c}$ & $2 \cdot 8$ & $3.8^{\mathrm{c}}$ & 0.3 & $1.8^{\mathrm{c}}$ & 0.08 \\
\hline Cellulose & $11 \cdot 2^{2 b}$ & 0.6 & $43^{2}$ & 1 & $163^{\mathrm{a}}$ & $11 \cdot 1$ & $25 \cdot 8^{\mathrm{a}}$ & 1.5 & $2 \cdot 1^{\mathrm{a}}$ & 0.10 \\
\hline Guar gum & $8.9^{\mathrm{c}}$ & $0 \cdot 3$ & $40^{\mathrm{ab}}$ & 1 & $99^{\mathrm{b}}$ & 7.5 & $13 \cdot 0^{\mathrm{b}}$ & 1.2 & $2 \cdot 1^{\mathrm{s}}$ & 0.05 \\
\hline EtOH oats & $11 \cdot 2^{\mathrm{ab}}$ & 0.4 & $40^{\mathrm{ab}}$ & 1 & $146^{\mathrm{a}}$ & $9 \cdot 9$ & $11 \cdot 5^{\mathrm{b}}$ & 0.7 & $1.6^{\mathrm{e}}$ & 0.10 \\
\hline Oats & $11 \cdot 6^{a}$ & 0.5 & $42^{\mathrm{s}}$ & 1 & $150^{\mathrm{a}}$ & $13 \cdot 5$ & $12 \cdot 3^{\mathrm{b}}$ & 0.7 & $1.9^{\mathrm{b}}$ & $0 \cdot 10$ \\
\hline EtOH oats + saponins & $10 \cdot 6^{\mathrm{ab}}$ & 0.4 & $39^{\mathrm{ab}}$ & 2 & $101^{b}$ & $18 \cdot 1$ & $11.7^{\mathrm{b}}$ & 1.5 & $1 \cdot 7^{\mathrm{c}}$ & $0 \cdot 10$ \\
\hline
\end{tabular}

${ }^{a-c}$ Means within columns with the same superscript letter were not significantly different $(P>0 \cdot 05)$.

EtOH oats, ethanol-extracted oats.

* For details of animals and diets, see Tables 1-3 and pp. 276-278.

$\dagger$ The feeding period was $21 \mathrm{~d}$ for gerbils, except for the cellulose diet which was fed for $16 \mathrm{~d}$, and $19 \mathrm{~d}$ for rats.

$2.5 \mathrm{mmol} / 1$, which was significantly higher than that of the other groups which was about $2 \mathrm{mmol} / \mathrm{l}$. The cholesterol content of the HDL fraction was significantly lower for the cellulose group than those for all other groups for gerbils and lower than those for the guargum, ethanol-extracted and normal oat groups in rats. The HDL-cholesterol values for the different oat groups were similar, regardless of the saponin content, about $2.5 \mathrm{mmol} / 1$ for the gerbils and about $1.2 \mathrm{mmol} / 1$ for the rats. For the gerbils, non-HDL-cholesterol values were lowest for the guar-gum group, intermediate for the oat groups and highest for the cellulose group. The rats had lower values which tended to be similar, ranging from 0.8 to $1.2 \mathrm{mmol} / \mathrm{l}$. The plasma triacylglycerol levels were not significantly different between the dietary groups.

\section{Liver weight and lipid content}

The liver weight was about $2 \mathrm{~g}$ for the gerbils and similar in all groups (Table 6). No differences were found in relative liver weights. For the rats the liver weights differed significantly and were lowest for the guar-gum and rat-pellet groups. The significant difference remained for the rat-pellet group but not for the guar-gum group when the liver weight was expressed as $\mathrm{g} / \mathrm{kg}$ body weight. The total lipid content was similar in the different groups of gerbils, but significantly lower in rats fed on pellets or guar gum than in those fed on cellulose, extracted oatmeal or unextracted oatmeal. There was also a significantly lower content of total liver lipids in the rats fed on the diet with added saponins, than in the oatmeal groups that were not supplemented with saponins.

Table 6 shows that there were pronounced differences in total liver cholesterol. For both species the cellulose group exhibited about twice the amount of the oatmeal groups; means for the gerbils were $10.4 v .6 .6 \mathrm{mg} / \mathrm{g}$ liver respectively and for the rats were $25.8 \mathrm{v} .11 .8 \mathrm{mg} / \mathrm{g}$ liver respectively. The rat-pellet group had the lowest value $(3.8 \mathrm{mg} / \mathrm{g}$ liver) and this was 
significantly lower than those for the other dietary groups. In the gerbils, free liver cholesterol was highest for the cellulose group. In the rat experiment the cellulose group and also the guar-gum group had a higher level of free cholesterol than the groups fed on oats.

\section{DISCUSSION}

Although the extracted oatmeal diet is referred to as having no saponins, it was not possible to obtain complete extraction of avenacosides A and B from oats. About $2 \%$ of the original amount remained, despite repeated extractions with ethanol. Compared with other studies, however, where a saponin-depleted material also was desired, this is a good result. In other studies using $800 \mathrm{ml}$ ethanol $/ \mathrm{l}$ only about $80 \%$ of the saponins were extracted (Potter et al. 1980; Topping et al. 1980; Calvert et al. 1982).

In some studies where saponins have been added to diets the intakes become lower, probably because of the bitter taste (Southon et al. 1988; Potter et al. 1993). Avenacosides A and B are bitter-tasting (Tschesche et al. 1969) but the levels used in the present study (maximum $0.7 \mathrm{~g} / \mathrm{kg} \mathrm{diet)} \mathrm{did} \mathrm{not} \mathrm{affect} \mathrm{the} \mathrm{intake} \mathrm{compared} \mathrm{with} \mathrm{the} \mathrm{other} \mathrm{groups,} \mathrm{for} \mathrm{any}$ of the species.

The mean weight gain of the gerbils was $7.8 \mathrm{~g}$ for the oatmeal groups, which is slightly less than that found in some previous studies (Mercer \& Holub, 1981; Andersen \& Holub, 1982), but similar to that in another recent study (Potter et al. 1993). Spontaneous deaths occurred in the cellulose group, possibly due to stress. A high mortality rate was reported in a previous study in which gerbils were fed on a $20 \mathrm{~g}$ cholesterol $/ \mathrm{kg}$ diet for several months (Temmerman et al. 1988). For the rats the mean weight gain for the oatmeal groups was $123.6 \mathrm{~g}$ and this did not differ from weight gains reported in the literature (Kritchevsky et al. 1984).

It was very important to balance the fatty acid compositions of the diets since the blood cholesterol level of gerbils is very sensitive to fat in the diet. Gerbils given diets containing no cholesterol, with $200 \mathrm{~g}$ safflower oil (11 g saturated fatty acids/100 g) or $190 \mathrm{~g}$ beef tallow $(50 \mathrm{~g}$ saturated fatty acids $/ 100 \mathrm{~g}) / \mathrm{kg}$ diet, exhibited blood cholesterol levels of 1.3 and $2.6 \mathrm{mmol} / 1$ respectively after $22 \mathrm{~d}$ of feeding (Leach \& Holub, 1984). Hegsted \& Gallagher (1967) gave diets containing $1 \mathrm{~g}$ cholesterol/kg to gerbils. The fats tested were safflower oil, olive oil and coconut oil $(200 \mathrm{~g} / \mathrm{kg}$ diet $)$ and after 2 weeks of feeding the cholesterol levels were $4.3,5.7$ and $6.4 \mathrm{mmol} / 1$ respectively. We had the same cholesterol and fat levels in our diets as those used in the Hegsted \& Gallagher (1967) study and obtained similar serum cholesterol levels $(4 \cdot 3-5 \cdot 1 \mathrm{mmol} / \mathrm{l})$.

Adding $5 \mathrm{~g}$ cholesterol $/ \mathrm{kg}$ to the diet given to rats did not affect plasma lipid values substantially compared with those of the group eating rat pellets with no cholesterol. Kritchevsky et al. (1984) gave a cellulose or an oat-bran diet containing $5 \mathrm{~g}$ cholesterol $/ \mathrm{kg}$ to rats for $21 \mathrm{~d}$ and, as with our findings, did not observe any differences in total plasma cholesterol. One way to obtain increased plasma cholesterol values in rats is to add cholic acid as well as cholesterol (Shinnick et al. 1990).

There were more pronounced effects on the plasma lipids in the gerbils and the total plasma cholesterol was higher than that in the rats, despite the lower content of cholesterol in the gerbil diets. In a comparative study the gerbils and rats exhibited plasma cholesterol levels of 7.2 and $1.7 \mathrm{mmol} / 1$ respectively on a diet containing $2 \mathrm{~g}$ cholesterol $/ \mathrm{kg}$ (Temmerman et al. 1988). The higher level for the gerbils was explained as being due to the fact that gerbils could not increase faecal steroid excretion as much as the rats.

The triacylglycerol levels were similar for all groups. In a study where oat bran or oat gum was given to rats, the oat gum but not the oat bran gave decreased triacylglycerol levels (Chen et al. 1981).

There were profound differences in total liver lipid levels between the dietary groups in 
rats and in liver cholesterol content in both species. The highest amount of saponins seemed to decrease the total liver lipid content as much as guar gum in rats, indicating some influence on the lipid metabolism in spite of the absence of effects on plasma lipids. The lowest levels of both total lipids and cholesterol in the liver were obtained in rats fed on pellets. In both species, oats as well as guar gum diminished considerably the liver cholesterol accumulation, but there was no specific effect of saponins. The total liver lipid content in our groups of rats is comparable with that of a previous study by Chen $e t$ al. (1981). The liver cholesterol content in the rats fed on pellets was similar (Shinnick et al. 1990) and that in the other groups of rats slightly higher (Kritchevsky et al. 1984) than that in previous studies.

The main purpose of the present study was to investigate whether saponins are involved in the hypocholesterolaemic effects of oats. The saponin levels in the diets used, therefore, were realistic compared with those found normally in oats. Earlier studies have diets with a higher saponin content. For example, Oakenfull et al. (1979) fed rats with a diet containing $10 \mathrm{~g}$ cholesterol $/ \mathrm{kg}$, and the addition of $10 \mathrm{~g}$ saponins from soapwort $/ \mathrm{kg}$ diet lowered the cholesterol accumulation, especially in the liver. The same results were obtained with $10 \mathrm{~g}$ soyabean saponins $/ \mathrm{kg}$ diet (Oakenfull et al. 1984). In another study rats were given soyabean flour high $(22 \mathrm{~g} / \mathrm{kg})$ or low $(4 \mathrm{~g} / \mathrm{kg})$ in saponins and with the same cholesterol content as in our study $(5 \mathrm{~g} / \mathrm{kg}$ diet; Topping et al. 1980). Both diets lowered plasma cholesterol, but there was no difference related to the saponin content. Adding a low amount $(2 \mathrm{~g} / \mathrm{kg}$ diet) of saponins from gypsophila roots to a diet also containing pectin in one study (Rotenberg \& Eggum, 1986) did not reduce plasma or liver cholesterol in rats compared with the saponin-free pectin diet.

Our study has shown that saponins play no significant role in the blood hypocholesterolaemic effects of oats. Thus, other components (especially $\beta$-glucan) are responsible for the hypocholesterolaemic effects of oats. Avenacosides A and B, nevertheless, could have some minor effects, as indicated by the liver lipid contents. Lipid metabolism in the body is complex, and measuring plasma and liver lipids provides some information. To obtain a better understanding, other variables should also be investigated. There are studies which show that saponins could increase the permeability of the gut (Johnson et al. 1986). Our knowledge of the physiological effects of saponins is still limited and more research is needed.

A grant from Nestec Ltd, Vevey, Switzerland, is gratefully acknowledged. The authors are indebted to Marcel A. Juillerat, Nestec Ltd Research Centre, Lausanne, for preparation of avenacosides $\mathbf{A}$ and $\mathbf{B}$ material and to Ulla Lindqvist and $\mathbf{K j e l l}$ Olsson for skilful technical assistance.

\section{REFERENCES}

Andersen, D. B. \& Holub, B. J. (1982). Effects of dietary cholesterol and type of dietary carbohydrate on hepatic and plasma glycerides and phospholipids in the gerbil. Journal of Nutrition 112, 1425-1436.

Andersson, H. (1992). The ileostomy model for the study of carbohydrate digestion and carbohydrate effects on sterol excretion in man. European Journal of Clinical Nutrition 46, Suppl. 2, S69-S76.

Asp, N.-G., Johansson, C.-G. \& Siljeström, M. (1983). Rapid enzymatic assay of insoluble and soluble dietary fibre. Journal of Agricultural Food Chemistry 31, 476-482.

Asp, N.-G., Mattsson, B. \& Önning, G. (1991). Variation in dietary fibre, $\beta$-glucan, starch, protein, fat and hull content of oats grown in Sweden 1987-1989. European Journal of Clinical Nutrition 46, 31-37.

Berg, H. (1990). Analysis of Fatty Acids. Intern Analysföreskrift. Kävlinge, Sweden: Swedish Meat Research Institute.

Bourgeois, C. F., Hel, S. H., Belliot, J. P., George, P. R. \& Slomianny, C. A. (1985). Disposable cartridge extraction of retinol and $\alpha$-tocopherol from feedstuffs. Journal of the Association of Official Analytical Chemists 68, 1121-1125.

Calvert, G. D. \& Yeates, R. A. (1982). Adsorption of bile salts by soya-bean flour, wheat bran, lucerne (Medicago 
sativa), sawdust and lignin; the effect of saponins and other plant constituents. British Journal of Nutrition 59 , 49-55.

Carlson, S. E. \& Goldfarb, S. (1977). A sensitive enzymatic method for the determination of free and esterified tissue cholesterol. Clinica Chimica Acta 79, 575-582.

Chen, W.-J. L. \& Anderson, J. W. (1984). Propionate may mediate the hypocholesterolemic effects of plant fibres in cholesterol fed rats. Proceedings of the Society for Experimental Biology and Medicine 175, $215-218$.

Chen, W.-J. L., Anderson, J. W. \& Gould, M. R. (1981). Effects of oat bran, oat gum and pectin on lipid metabolism of cholesterol-fed rats. Nutrition Reports International 24, 1093-1098.

EU Method. (1971). Crude fat determination. Official Journal of the European Communities L279, 995.

Folch, J., Lees, M. \& Sloane Stanley, G. H. (1957). A simple method for the isolation and purification of total lipids from animal tissues. Journal of Biological Chemistry 226, 497-509.

Gordon, S., \& Cekleniak, W. P. (1961). Serum lipoprotein pattern of the hypercholesterolemic gerbil. American Journal of Physiology 201, 27-28.

Håkansson, B., Jägerstad, M. \& Öste, R. (1987). Determination of vitamin E in wheat products by HPLC. Journal of Micronutritional Analysis 3, 307-318.

Hegsted, D. M. \& Gallagher, A. (1967). Dietary fat and cholesterol and serum cholesterol in the gerbil. Journal of Lipid Research 8, 210-214.

Holm, J., Björck, I., Drews, A. \& Asp, N.-G. (1986). A rapid method for the analysis of starch. Starch 7, $224-226$.

Illman, R. J. \& Topping, D. L. (1985). Effects of dietary oat bran on faecal steroid excretion, plasma volatile fatty acids and lipid synthesis in rats. Nutrition Research $5,839-846$.

Johnson, I. T., Gee, J. M., Price, K. R., Curl, C. L. \& Fenwick, G. R. (1986). Influence of saponins on gut permeability and active nutrient transport in vitro. Journal of Nutrition 116, 2270-2277.

Kritchevsky, D., Tepper, S. A., Goodman, G. T., Weber, M. M. \& Klurfeld, D. M. (1984). Influence of oat and wheat bran on cholesterolemia in rats. Nutrition Reports International 29, 1353-1359.

Leach, A. B. \& Holub, B. J. (1984). The effect of dietary lipid on the lipoprotein status of the Mongolian gerbil. Lipids 19, 25-33.

Lütz, C. (1980). The determination of prolamellar bodies and saponins in etioplasts and leaves of Avena sativa $\mathrm{L}$. Zeitung für Naturforschung 35c, $519-521$.

McCleary, B. V. \& Glennie-Holmes, M. (1985). Enzymic quantification of (1-3)(1-4)- $\beta$-D-glucan in barley and malt. Journal of the Institute of Brewing 91, 285-295.

Mercer, N. J. H. \& Holub, B. J. (1991). Measurement of hepatic sterol synthesis in the Mongolian gerbil in vivo using [ $\left.{ }^{3} \mathrm{H}\right]$ water: diurnal variation and effect of type of dietary fat. Journal of Lipid Research 22, 792-799.

Nicolosi, R. J., Marlett, J. A., Morello, A. M., Flanagan, S. A. \& Hegsted, D. M. (1981). Influence of dietary unsaturated and saturated fat on the plasma lipoproteins of Mongolian gerbils. Atherosclerosis 38, 359-371.

Nyman, M., Schweizer, T. F., Tyrén, S., Reimann, S. \& Asp, N.-G. (1990). Fermentation of vegetable fiber in the intestinal tract of rats and effects on faecal bulking and bile acid excretion. Journal of Nutrition 120, 459-466.

Oakenfull, D. G., Fenwick, D. E. \& Hood, R. L. (1979). Effects of saponins on bile acids and plasma lipids in the rat. British Journal of Nutrition 42, 209-216.

Oakenfull, D. G., Topping, D. L., Illman, R. J. \& Fenwick, D. E. (1984). Prevention of dietary hypercholesterolaemia in the rat by soya bean and Quillaja saponins. Nutrition Reports International 29, $1039-1045$.

Önning, G. \& Asp, N.-G. (1993). Analysis of saponins in oat kernels. Food Chemistry 48, 301-305.

Önning, G., Juillerat, M. A., Fay, L. \& Asp, N.-G. (1994). Degradation of oat saponins during heat processingeffect of pH, stainless steel and iron at different temperatures. Journal of Agricultural Food Chemistry 42 , 2578-2582.

Potter, J. D., Illman, R. J., Calvert, G. D., Oakenfull, D. G. \& Topping, D. L. (1980). Soya saponins, plasma lipids, lipoproteins and faecal bile acids: a double blind cross-over study. Nutrition Reports International 22 , 521-528.

Potter, S. M., Jiminez-Flores, R., Pollack, J., Lone, T. A. \& Berber-Jiminez, M. D. (1993). Protein-saponin interaction and its influence on blood lipids. Journal of Agricultural Food Chemistry 41, 1287-1291.

Price, K. R., Johnson, I. T. \& Fenwick, G. R. (1987). The chemistry and biological significance of saponins in foods and feeding stuffs. CRC Critical Reviews on Food Science and Nutrition 26, 27-135.

Querishi, A. A., Burger, W. C., Peterson, D. M. \& Eison, C. E. (1986). The structure of an inhibitor of cholesterol biosynthesis isolated from barley. Journal of Biological Chemistry 362, 10544-10550.

Ripsin, C. M. \& Keenan, J. M. (1992). The effects of dietary oat products on blood cholesterol. Trends in Food Science and Technology 3, 137-141.

Rotenberg, S. \& Eggum, B. O. (1986). The effect of purified pectins with and without saponins in the diet on selected lipid parameters in liver and blood plasma of rats. Acta Agriculturae Scandinavica 36, $211-216$.

Shinnick, F. L., Ink, S. L. \& Marlett, J. A. (1990). Dose response to a dietary oat bran fraction in cholesterol-fed rats. Journal of Nutrition 120, 561-568.

Southon, S., Johnson, I. T., Gee, J. M. \& Price, K. R. (1988). The effect of gypsophila saponins in the diet on mineral status and plasma cholesterol concentration in the rat. British Journal of Nutrition 59, 49-55.

Story, J. A., LePage, S. L., Petro, M. S., West, L. G., Cassidy, M. M., Lightfoot, F. G. \& Vahouny, G. L. (1984). Interactions of alfalfa plant and sprout saponins with cholesterol in vitro and in cholesterol-fed rats. American Journal of Clinical Nutrition 39, 917-929. 
Temmerman, A. M., Vonk, R. J., Niezen-Koning, K., Berger, R. \& Fernandes, J. (1988). Long-term and shortterm effects of dietary cholesterol and fats in the Mongolian gerbil. Annals of Nutrition \& Metabolism 32, $177-185$.

Topping, D. L., Storer, G. B., Calbert, G. D., Illman, R. J., Oakenfull, D. G. \& Weller, R. A. (1980). Effects of dietary saponins on faecal bile acids and neutral sterols, plasma lipids, and lipoprotein turnover in the pig. American Journal of Clinical Nutrition 33, 783-786.

Tschesche, R. \& Lauren, P. (1971). Avenacoside B, ein sweites bisdesmosidisches Steroidsaponin aus Avena sativa (A second bisdesmosidic steroid saponin from Avena sativa). Chemische Berichtung 104, 3549-3555.

Tschesche, R., Tauser, M., Fehlhaber, H.-W. \& Wulf, G. (1969). Avenacoside A, ein bisdesmosidisches Steroidsaponin aus Avena sativa (A bisdesmosidic steroid saponin from Avena sativa). Chemische Berichtung 102, 2072-2082. 